\title{
SUITABILITY OF THE TETRAZOLIUM TEST METHODOLOGY FOR RECENTLY HARVESTED AND STORED COFFEE SEEDS
}

\author{
Adequação da metodologia do teste de tetrazólio para sementes de \\ café recém colhidas e armazenadas
}

\author{
Aline da Consolação Sampaio Clemente', Maria Laene Moreira de Carvalho², Renato Mendes Guimarães ${ }^{2}$
}

\begin{abstract}
Germination of coffee seeds occurs in a slow and non-uniform manner and the tetrazolium test (TZ) may be a quick alternative for assessment of viability, as long as the preparation and imbibition of the seeds is established. This study was performed in two stages: in the first, recently harvested seeds from three coffee cultivars were submitted to four methodologies for removal of the parchment: manual extraction or use of sodium hypochlorite $(\mathrm{NaClO}$ at $5 \%)$ and two periods of imbibition of the seeds in water ( 36 and 48 hours) for removal of the embryos. In the second phase, manual removal and the use of $\mathrm{NaClO}$ were compared for elimination of the parchment of stored seeds for monthly performance of the tetrazolium test for six months. Sodium hypochlorite is not efficient in total extraction of the parchment and has a negative effect on the results of the TZ test on low moisture coffee seeds. An imbibition time of 48 hours facilitates extraction of embryos and does not affect test results. The tetrazolium test on coffee seeds with different moisture and deterioration levels must be undertaken with manual removal of the parchments.
\end{abstract}

Index terms: Coffea arabica, viability, parchment.

\section{RESUMO}

A germinação de sementes de café ocorre de forma lenta e desuniforme e o teste de tetrazólio (TZ) pode ser uma alternativa rápida para a avaliação da viabilidade, desde que os procedimentos de preparação e embebição das sementes estejam estabelecidos. $\mathrm{O}$ trabalho foi realizado em duas etapas: na primeira, sementes recém-colhidas de cinco cultivares de cafeeiro foram submetidas a quatro metodologias para remoção do pergaminho: extração manual ou utilização de hipoclorito de sódio ( $\mathrm{NaClO}$ a $5 \%)$ e dois períodos de embebição das sementes em água (36 e 48 horas) para a retirada dos embriões. Na segunda fase, foi comparada a remoção manual e a utilização de $\mathrm{NaClO}$ para a eliminação do pergaminho de sementes armazenadas para realização mensal do teste de tetrazólio durante seis meses. O hipoclorito de sódio não é eficiente para a extração total do pergaminho e afeta negativamente os resultados do teste de TZ em sementes de café com baixa umidade. O tempo de embebição de 48 horas facilita a extração dos embriões e não afeta os resultados do teste. $\mathrm{O}$ teste de tetrazólio em sementes de café, com diferentes níveis de umidade e deterioração, deve ser realizado com a remoção manual dos pergaminhos.

Termos para indexação: Coffea arabica, viabilidade, pergaminho.

(Received in may 2, 2012 and approved in july 3, 2012)

\section{INTRODUCTION}

Coffee is considered to be a product of high commercial value, being produced and consumed in various countries. The coffee plant is propagated by seedlings, which requires the use of high quality seeds; nevertheless, problems with sensitivity of seeds to desiccation and the slowness of the germination process create difficulties for obtaining quick and consistent results regarding the quality of the commercial lots.

Germination of coffee seeds occurs in a slow and non-uniform way (EIRA et al., 2006), up to 30 days under laboratory conditions (BRASIL, 2009), and there are some aspects that contribute to this situation, which are: lack of uniformity of ripening of the fruit, post-harvest processes, such as rapid drying and inadequate storage (ROSA et al. 2011), the presence of the spermoderm, also known as "silver skin", which contains natural inhibitors (PEREIRA et al., 2002) and the presence of the endocarp or "parchment" which is considered to be the principal characteristic responsible for delay in germination (SALES, 2006).

Removal of the endocarp may be performed by mechanical and manual methods. The mechanical method causes damage to the seeds, whereas the manual method is laborious and requires a large number of workers (ARAÚJO et al., 2004).

An alternative proposed by Meireles et al. (2007) to facilitate removal of the endocarp is utilization of a sodium hypochlorite solution at a concentration of $5.0 \%$ for 6

\footnotetext{
1Universidade Federal de Lavras/UFLA-Departamento de Agricultura/DAG - Cx. P. 3037-37200-000 - Lavras - MG - Brasil - alineagrolavras@gmail.com 'Universidade Federal de Lavras/UFLA - Departamento de Agricultura/DAG - Lavras - MG - Brasil
} 
hours. Nevertheless, Sofiatti et al. (2009) observed a negative effect of hypochlorite for seeds with a moisture content below $23 \%$ in germination test results. In addition, Rubim et al., (2010) observed that "conilon" coffee seeds exhibited low germination when submitted to sodium hypochlorite aqueous solution at a concentration of $4 \%$ for three hours, in addition to complete degradation of the parchment not being observed.

Various studies have been conducted seeking to reduce the period for obtaining the results of assessment of physiological potential of lots of coffee, such as the visual assessment test of exudates (SERA; MIGLIORANZA, 2003), the Lercafé test, used to assess coffee seed quality (ZONTA et al., 2009), and the tetrazolium test (DIAS; SILVA, 1986; VIEIRA et al. 1998) and germination test assessment at earlier stages of the seedlings (ROSA et al., 2010). One of these tests is the tetrazolium test, which is based on the activity of dehydrogenase enzymes (MOORE, 1972) and has proved to be an interesting alterative due to its accuracy and speed in determination of viability, obtaining results in approximately 48 hours for coffee seeds (DIAS; SILVA, 1986; VIEIRA et al., 1998).

In order to undertake the tetrazolium test, in addition to removal of the parchment, there is the need for extraction of the embryo, which may only be performed on moistened seeds since the endosperm is a very hard tissue. According to Dias and Silva (1986), the seeds should be soaked in water for 18 hours, and the embryo should be removed and soaked in tetrazolium solution at $1 \%$ for 24 to 28 hours more at $30^{\circ} \mathrm{C}$, protected from light. Vieira et al. (1998), for their part, reported that the conditioning period for seeds varies in terms of their age, with 18 to 24 hours being recommended for recently harvested seeds and 72 hours for stored seeds. Zonta et al. (2009) also suggested a pre-soaking of 24 hours at $30^{\circ} \mathrm{C}$, then extraction of the embryo and soaking in Tetrazolium solution $(0.1 \%)$ at $35^{\circ} \mathrm{C}$ for a period of 16 hours.

Due to variations of the recommended methodologies, this study was undertaken for the purpose of verifying the effect of sodium hypochlorite on removal of the endocarp and of imbibition time for extraction of the embryo in performance of the tetrazolium test on recently harvested and on stored coffee seeds.

\section{MATERIAL AND METHODS}

The experiment was conducted at the Central Seed Laboratory of the School of Agriculture of the Universidade Federal de Lavras (UFLA), Minas Gerais, Brazil. Coffee seeds recently harvested from the region of Lavras and Southern Minas Gerais were used which presented different moisture content and physiological quality. The experiment was conducted in two phases; in the first stage, recently harvested coffee seeds from four lots of the cultivars Catuaí IAC 99, Catuaí Vermelho IAC 144 and Acaiá IAC 479-19 were submitted to four methodologies for removal of the parchment: manual extraction or use of sodium hypochlorite ( $\mathrm{NaClO}$ at $5 \%$ ) and two periods of imbibition of the seeds in water (36 and 48 hours) for the removal of the embryos. In the second phase, manual removal and use of $\mathrm{NaClO}$ were compared for elimination of the parchment of stored seeds for monthly performance of the tetrazolium test throughout a six month period of the cultivars Mundo Novo 376-4, Topázio MG1190, Catuaí IAC 99, Catuaí Vermelho IAC 144 and Acaiá IAC 479-19.

\section{1st Phase}

Four methodologies were assessed for execution of the tetrazolium test: two methods for removal of the parchments and two periods of imbibition of the seeds for removal of the embryos. Removal of the parchment was carried out by imbibition of 400 seeds in a $200 \mathrm{ml}$ solution of sodium hypochlorite $(\mathrm{NaClO})$ at $5 \%$ for 6 hours at a temperature of $25^{\circ} \mathrm{C}$, according to Meireles et al. (2007). This method for removal was compared to the conventional method, in which the parchment is manually removed. For extraction of the embryos, the seeds were directly soaked in water for the periods of 36 and 48 hours at a temperature of $30^{\circ} \mathrm{C}$.

Tetrazolium test: Four replications of 50 seeds were used for each treatment. After the periods of imbibition (36 and 48 hours), the embryos were extracted and maintained in an antioxidant solution with polyvinylpyrrolidone (PVP) from the time of their extraction until being placed in the $0.5 \%$ tetrazolium solution. Staining was performed, keeping the embryos in the dark at a temperature of $30^{\circ} \mathrm{C}$ for 2 hours. Assessment was performed under stereoscopic magnifying glasses (10X) by making a longitudinal section of the embryos, which were classified as viable and nonviable in accordance with the location and extension of the damage observed (Figures 1and 2).

Germination Test: Four replications of 50 seeds without parchment (manually extracted) were used for each treatment. Seeding was made on "germitest" type (paper rolls) paper toweling, moistened with distilled water in the amount of two and a half times the weight of the dry paper and placed to germinate at a constant temperature of $30^{\circ} \mathrm{C}$ in the presence of light. Final counting was made on the 30th day after seeding, counting the number of normal plantlets in each replication (Figures 3 and 4), in accordance with the criteria established by the Seed Analysis Rules (BRASIL, 2009). 


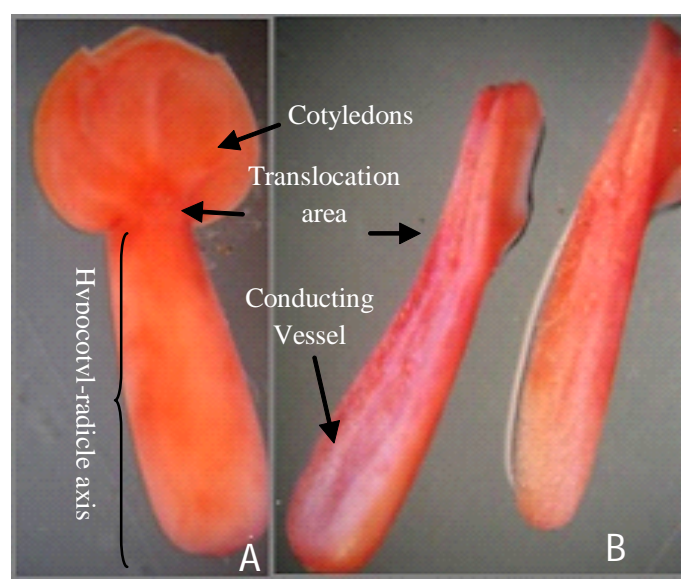

Figure 1 - Viable embryo-cotyledons, hypocotyl-radicle axis and translocation area stained by tetrazolium salt (A). Detail of the section indicating stained conducting tissues (B).

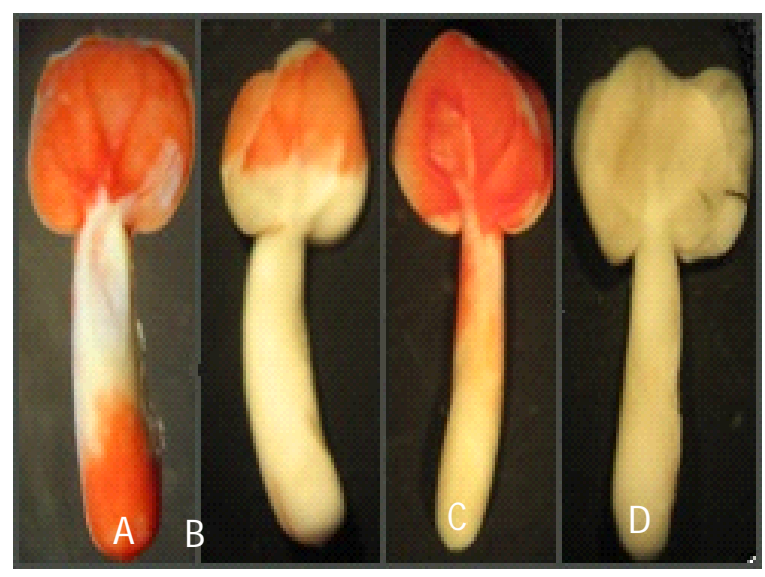

Figure 2 - Non-viable coffee embryos with damage at the point of connection between the cotyledons and the hypocotyl-radicle axis (A, B), damage caused by sodium hypochlorite (C) and totally unstained (D).

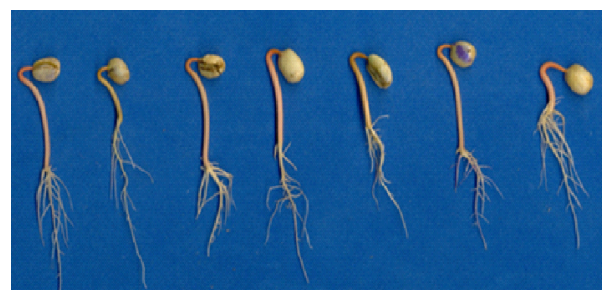

Figure 3 - Normal coffee seedlings at 30 days after seeding.

Determination of moisture degree: Performed by the drying oven method at $105^{\circ} \mathrm{C}$ for 24 hours (BRASIL, 2009). The results were expressed in mean percentage per sample.

\section{2nd Phase}

One lot from each cultivar used in the first phase of the experiment was stored for six months under ambient conditions (without control of temperature and relative air humidity) and, every 30 days, the seeds were assessed by the germination and tetrazolium tests and determination of moisture. The manual extraction method of the parchment was compared to the sodium hypochlorite method and the imbibition time was 48 hours $\left(30^{\circ} \mathrm{C}\right)$.

The variations of relative air humidity and temperature in the storage environment were measured with the aid of a thermo-hygrometer.

Statistical procedures: In the first phase, the experimental design used was entirely randomized with a 4 × 2 × 2 factorial design (four lots, two methodologies of extraction of the parchment and two imbibition times) for each cultivar separately. In the second phase, a factorial design $2 \times 6$ was used, consisting of two methodologies of extraction of the parchment and six storage times. Analysis of variance of the data and means comparison was made by the Scott-Knott test at $5 \%$ probability (qualitative characteristics) by means of the statistical program SISVAR ${ }^{\circledR}$ (Ferreira, 2000). The statistical analyses for comparison between the results of

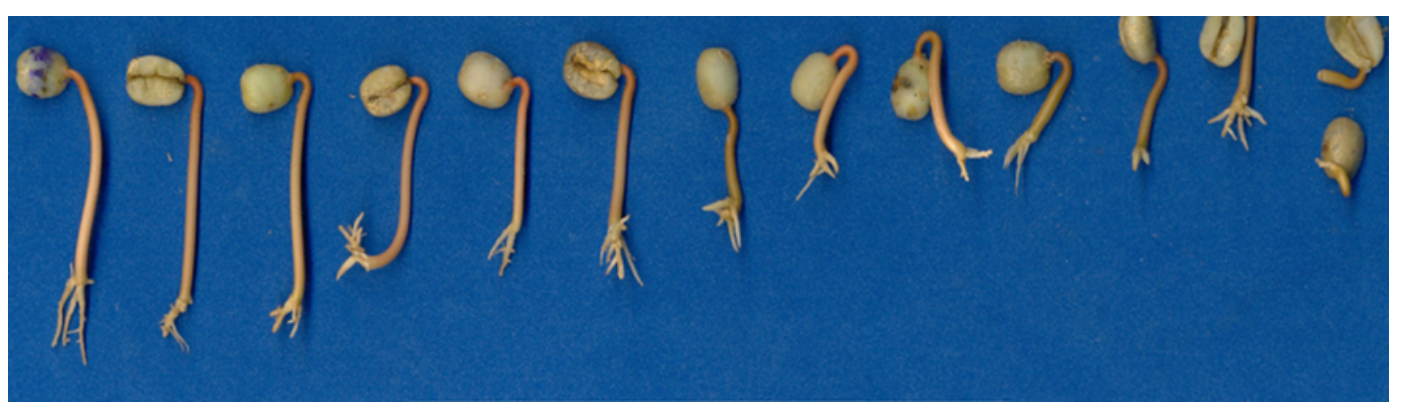

Figure 4-Abnormal coffee seedlings with deficient or absent primary root and poorly developed hypocotyl (short and thick).

Ciênc. agrotec., Lavras, v. 36, n. 4, p. 415-423, jul./ago., 2012 
the germination test and of the tetrazolium test were performed considering binomial distribution (with canonical or logistic link function). Assessment of the difference among methodologies and the effect of time were observed by means of contrasts and through reduction in the residual deviance of the sequential adjustment of models. The procedure was developed on the software R (R DEVELOPMENT CORE TEAM, 2008).

\section{RESULTS AND DISCUSSION}

\section{Phase 1}

The effects of sodium hypochlorite, used for extraction of the parchment of coffee seeds, on the viability assessed by the tetrazolium test varied in accordance with the lots. In table 1 , lower viability values of the seeds may be observed when the sodium hypochlorite solution was used for the removal of the parchment in most of the lots of the three cultivars studied. Only lot 3 of the cultivar Catuaí IAC-99 and lots 2 and 3 of the cultivar Acaiá IAC 479-19 were not negatively affected by the use of sodium hypochlorite for extraction of the parchment.

In carrying out the experiment, it was observed that the sodium hypochlorite solution $(6 \%)$ was not efficient in bringing about total degradation of the parchments, with manual removal of remaining parchments of stored seeds being necessary. In addition, in phase 1 , a negative effect on coffee seed viability was observed when sodium hypochlorite was used in extraction of the parchments of seeds with moisture below 25\% (Table 1). According to Sofiatti et al. (2009), the lower the initial degree of moisture of the seeds, the greater the absorption of the hypochlorite solution, which leads to degradation of the membranes, less selectivity, greater susceptibility to the entry of solutes, and faster absorption, causing loss of viability of these seeds.
The negative effect of sodium hypochlorite was also observed by Rubim et al. (2010) on conilon coffee seeds.

From the results of the tetrazolium test in reference to conditioning time (Table 2), it may be observed that the viability data of the pre-conditioned seeds in the time of 48 hours was greater for most of the lots of the three cultivars, with the exception of lot 3 of the cultivar Catuaí IAC-99 and lot 3 of the cultivar Catuaí Vermelho IAC-144.

In the period of 48 hours of imbibition, seed performance was greater than or equal to seeds soaked for 36 hours, and these results appear not to be influenced by moisture content or initial quality of the seeds. According to Dias and Silva (1986), for softening of the endosperm in removal of the embryo, the seeds should be soaked for 18 to 24 hours at $30^{\circ} \mathrm{C}$; however, from analysis of pre-test results (data not presented), it may be inferred that the time indicated is insufficient to soften the seeds, which hinders extraction of the embryos. Vieira et al. (1998) report that coffee seeds should be soaked in water for a longer period for there to be sufficient activation of the enzyme system, which improves and makes the staining procedure quicker, with pre-conditioning periods of up to 72 hours being recommended. In addition, a longer imbibition period facilitates excision of embryos. In the present study, better performance of the seeds soaked for a longer period (48 hours) was also observed, in addition to facility in extraction of the embryo through softening of the seed endosperm.

The means of the germination percentages of the three cultivars are presented in table 3 . It may be observed that the lots present different levels of quality and are within the minimum germination standards $(70 \%)$ required for sale of coffee seeds in Brazil in accordance with the Administrative Ruling (Portaria) no. 482 of the Instituto Mineiro de Agropecuária - IMA (2001).

Table 1 - Mean viability percentages of seeds and moisture content of three coffee cultivars submitted to two methodologies of parchment extraction (manual - $\mathrm{M}$ and with sodium hypochlorite - $\mathrm{H}$ ) and assessed by the tetrazolium test.

\begin{tabular}{|c|c|c|c|c|c|c|c|c|c|}
\hline \multicolumn{10}{|c|}{ Cultivars } \\
\hline \multirow{3}{*}{ Lot } & \multirow{3}{*}{$\stackrel{\rho}{b}$} & \multirow{2}{*}{\multicolumn{2}{|c|}{$\begin{array}{c}\text { Catuaí IAC-99 } \\
\text { Parchment Extraction } \\
\text { Method }\end{array}$}} & \multirow{3}{*}{$\stackrel{\circ}{b}$} & \multirow{2}{*}{\multicolumn{2}{|c|}{$\begin{array}{c}\text { Catuaí Vermelho IAC } 144 \\
\text { Parchment Extraction } \\
\text { Method }\end{array}$}} & \multirow{3}{*}{$\stackrel{8}{b}$} & \multirow{2}{*}{\multicolumn{2}{|c|}{$\begin{array}{c}\text { Acaía IAC 479-19 } \\
\text { Parchment Extraction } \\
\text { Method }\end{array}$}} \\
\hline & & & & & & & & & \\
\hline & & M & $\mathrm{H}$ & & M & $\mathrm{H}$ & & $\mathrm{M}$ & $\mathrm{H}$ \\
\hline 1 & 21.0 & $83.25 \mathrm{Aa}$ & $79.00 \mathrm{Bc}$ & 19.5 & $90.50 \mathrm{Aa}$ & $85.25 \mathrm{Ba}$ & 21.5 & $84.25 \mathrm{Aa}$ & $78.75 \mathrm{Bb}$ \\
\hline 2 & 21.5 & $77.75 \mathrm{Ab}$ & $69.25 \mathrm{Ba}$ & 19.5 & $84.75 \mathrm{Ac}$ & $81.25 \mathrm{Bb}$ & 33.0 & $81.25 \mathrm{Ab}$ & $81.00 \mathrm{Aa}$ \\
\hline 3 & 29.5 & $83.25 \mathrm{Aa}$ & $81.75 \mathrm{Ad}$ & 19.0 & $87.25 \mathrm{Ab}$ & $81.75 \mathrm{Bb}$ & 27.0 & $83.25 \mathrm{Aa}$ & $82.25 \mathrm{Aa}$ \\
\hline 4 & 25.0 & $78.75 \mathrm{Ab}$ & $75.25 \mathrm{Bb}$ & 19.0 & $86.25 \mathrm{Ab}$ & $80.25 \mathrm{Bb}$ & 22.0 & $76.87 \mathrm{Ac}$ & $73.00 \mathrm{Bc}$ \\
\hline
\end{tabular}

Means followed by the same capital letter in the row and small letter in the column for each cultivar do not differ among themselves by the Scott-Knott Test at the nominal significance level of $5 \%$.

Ciênc. agrotec., Lavras, v. 36, n. 4, p. 415-423, jul./ago., 2012 
Table 2 - Mean viability percentages and moisture content of seeds of three coffee cultivars submitted to two preconditioning periods and assessed by the tetrazolium test.

\begin{tabular}{|c|c|c|c|c|c|c|c|c|c|}
\hline \multicolumn{10}{|c|}{ Cultivars } \\
\hline \multirow{3}{*}{ Lot } & \multirow{3}{*}{$\stackrel{\partial}{b}$} & Catuaí & AC-99 & \multirow{3}{*}{$\stackrel{\circ}{b}$} & Catuaí V & n. IAC 144 & \multirow{3}{*}{$\stackrel{80}{b}$} & \multirow{2}{*}{\multicolumn{2}{|c|}{$\begin{array}{c}\text { Acaía IAC 479-19 } \\
\text { Pre-conditioning time }\end{array}$}} \\
\hline & & \multicolumn{2}{|c|}{ Pre-conditioning time } & & \multicolumn{2}{|c|}{ Pre-conditioning time } & & & \\
\hline & & 36 & 48 & & 36 & 48 & & 36 & 48 \\
\hline 1 & 21.0 & $81.50 \mathrm{Ab}$ & $80.75 \mathrm{Aa}$ & 19.5 & $84.75 \mathrm{Bb}$ & $91.00 \mathrm{Aa}$ & 21.5 & $79.75 \mathrm{Bb}$ & $83.25 \mathrm{Aa}$ \\
\hline 2 & 21.5 & $72.25 \mathrm{Bd}$ & $74.75 \mathrm{Ac}$ & 19.5 & $82.00 \mathrm{Bc}$ & $84.00 \mathrm{Ac}$ & 33.0 & $81.00 \mathrm{Ab}$ & $81.25 \mathrm{Aa}$ \\
\hline 3 & 29.5 & $84.00 \mathrm{Aa}$ & $81.00 \mathrm{Ba}$ & 19.0 & $87.00 \mathrm{Aa}$ & $82.00 \mathrm{Bd}$ & 27.0 & $82.75 \mathrm{Aa}$ & $82.75 \mathrm{Aa}$ \\
\hline 4 & 25.0 & $76.75 \mathrm{Ac}$ & $77.25 \mathrm{Ab}$ & 19.0 & $80.00 \mathrm{Bd}$ & $86.50 \mathrm{Ab}$ & 22.0 & $73.12 \mathrm{Bc}$ & $76.75 \mathrm{Ab}$ \\
\hline
\end{tabular}

Means followed by the same capital letter in the row and small letter in the column for each cultivar do not differ among themselves by the Scott-Knott Test at the nominal significance level of $5 \%$.

Table 3 - Mean germination percentage of recently harvested seeds from 4 lots of 3 coffee cultivars.

\begin{tabular}{cccc}
\hline \multirow{2}{*}{ Lot } & \multicolumn{3}{c}{ Germination $(\%)$} \\
\cline { 2 - 4 } & Catuaí IAC-99 & Catuaí Vermelho IAC 144 & Acaía IAC 479-19 \\
\hline 1 & $78.25 \mathrm{~b}$ & $86.00 \mathrm{a}$ & $79.25 \mathrm{a}$ \\
2 & $74.00 \mathrm{c}$ & $77.00 \mathrm{c}$ & $78.25 \mathrm{a}$ \\
3 & $83.75 \mathrm{a}$ & $79.50 \mathrm{a}$ & $79.50 \mathrm{a}$ \\
4 & $74.00 \mathrm{c}$ & $81.00 \mathrm{~b}$ & $74.50 \mathrm{~b}$ \\
\hline
\end{tabular}

Means followed by the same small letter in the column for each cultivar do not differ among themselves by the Scott-Knott Test at the nominal significance level of $5 \%$.

In table 4 are presented only the mean values of the cultivars submitted to the germination test and to the four tetrazolium methodologies since the behavior of the cultivars in relation to the methodologies did not differ among themselves. Comparison is made between germination and each methodology of the tetrazolium test.

Table 4 - Contrasts among percentages of germination and of viability with the use of 4 methodologies for performance of the tetrazolium test (extraction of the parchment with sodium hypochlorite or manually and imbibition for 36 and $48 \mathrm{~h}$.).

\begin{tabular}{lc}
\hline Method & \% Means \\
\hline $\begin{array}{c}\text { Germination } \\
\text { imbibition) }\end{array}$ & 81.4 \\
Viability (sodium hypochlorite; $36 \mathrm{~h}$. & $80.0^{\mathrm{ns}}$ \\
$\begin{array}{c}\text { Viability (sodium hypochlorite; } 48 \mathrm{~h} . \\
\text { imbibition) }\end{array}$ & $81.6^{\mathrm{ns}}$ \\
Viability (Manual; 36 h. imbibition) & $83.7^{*}$ \\
Viability (Manual; 48 h. imbibition) & $85.4^{*}$ \\
\hline "ns" not significant compared to the germination test by the \\
t test (5\%).
\end{tabular}

The mean results of germination of the cultivars are similar to the results of the tetrazolium tests when extraction of the parchment with sodium hypochlorite solution and with 36 and 48 hours of imbibition was used, differing from the other methodologies. However, the seed viability results were greater when manual extraction of the parchments was performed, both in relation to the treatment with sodium hypochlorite in the tetrazolium test and the germination percentage.

According to França Neto, Krzyzanowski and Costa (1998) and Krzyzanowski, Vieira and França Neto (1999) differences of up to $5 \%$ between the viability test and germination test are acceptable. In the present study, greater viability potential was observed with manual extraction of the parchment. Thus, the negative interference of the use of sodium hypochlorite on performance of the tetrazolium test could be observed.

\section{Phase 2}

Results of the moisture content of the coffee seeds throughout the storage period are presented in figure 5 . A decline in the moisture level of the seeds in the first month of storage may be observed in all the cultivars. 
This reduction in the seed moisture level coincides with the lower relative air humidity values (Figure 6) in the months of July and August (55\% RH) in the storage conditions. In the subsequent months, seed moisture content remained balanced, with small variations being noted up to the end of storage.

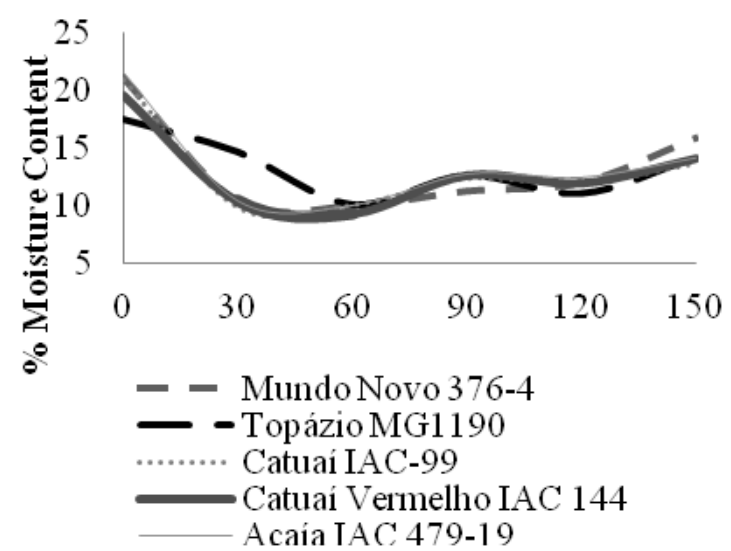

Figure 5 - Moisture content (\%) in coffee seeds throughout storage time under non-controlled conditions. UFLA, Lavras - MG.

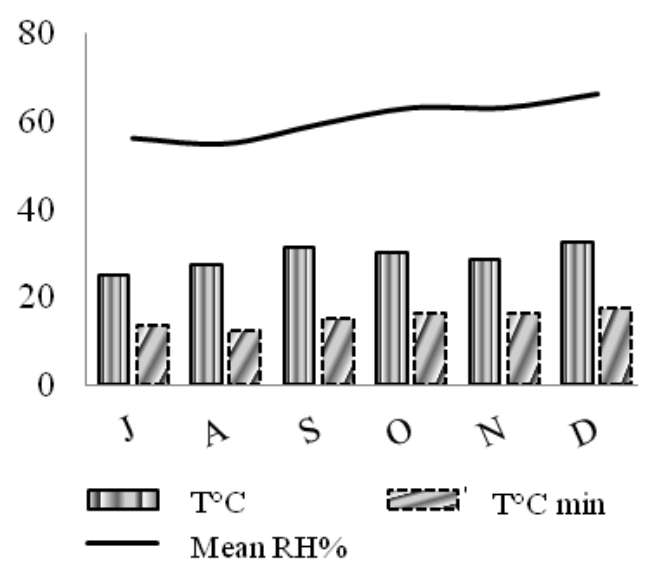

Figure 6-Temperature and relative air humidity throughout six months of storage under non-controlled conditions at the seed breeding unit of UFLA. Lavras - MG.

The germination test was performed at six different storage times (Figure 7). From the results, maximum germination potentials for the unstored seeds and those with 30 days of storage may be observed. As of the second month, the germination potential of the seeds decreases for all the cultivars throughout time, reaching values from
$30 \%$ (Topázio MG1190) to $8 \%$ of germination (Mundo Novo 376-4) at 150 days of storage.

Moisture reduction already in the first 30 days of storage may have brought about acceleration in the seed deterioration process, observed through reduction of the germination and viability values as of 60 days of storage. These results corroborate those obtained by Vasconcelos, Groth and Razera (1992) and Soto, Echevarria and Rodriguez (1995), Rosa et al. (2011) who observed a reduction in coffee seed viability with moisture content from $15 \%$ to $25 \%$, principally when the seeds are stored in non-controlled conditions (VIEIRA et al., 2007), which promotes hygroscopic equilibrium of the seeds at low moisture content, characterizing intermediate behavior of the species in relation to desiccation.

The effect of the treatments for removal of the parchment on the results of the tetrazolium test of stored seeds may be observed in figure 7 . The seeds soaked in hypochlorite solution exhibit lower viability values in comparison with the treatment where the parchment was manually removed.

Considering that all the lots of seeds stored contained low moisture values $(<23 \%)$ since the beginning of storage, the results observed in this phase confirm the hypothesis that under low moisture conditions, the effects of sodium hypochlorite are more accentuated, affecting not only the germination test (MEIRELES et al., 2007; SOFIATTI et al., 2009, RUBIM et al., 2010) but also seed viability.

Loss of seed viability follows the same trend for the seeds submitted to the two methodologies for embryo extraction, with different values for all the storage times, and this difference was observed in all the cultivars studied. Sofiatti et al. (2009) report that the sodium hypochlorite reaction may lead to increase in the temperature of the pre-soaking solution, which favors greater absorption of the solution by the seeds. Bewley and Black (1982) affirm that exposure of seeds to sodium hypochlorite for long periods may cause damage to the embryo since sodium hypochlorite is a strong oxidant.

In the present study, the coffee seeds were exposed to the solution for 6 hours, which may have caused greater absorption of substances harmful to the embryo, an effect observed in embryos which exhibited damages to the radicle. In addition to the negative effect of sodium hypochlorite, it was not efficient in degradation of the parchment of stored seeds. Just as in the recently harvested seeds, there was the need for manual removal of the remaining parchments. 

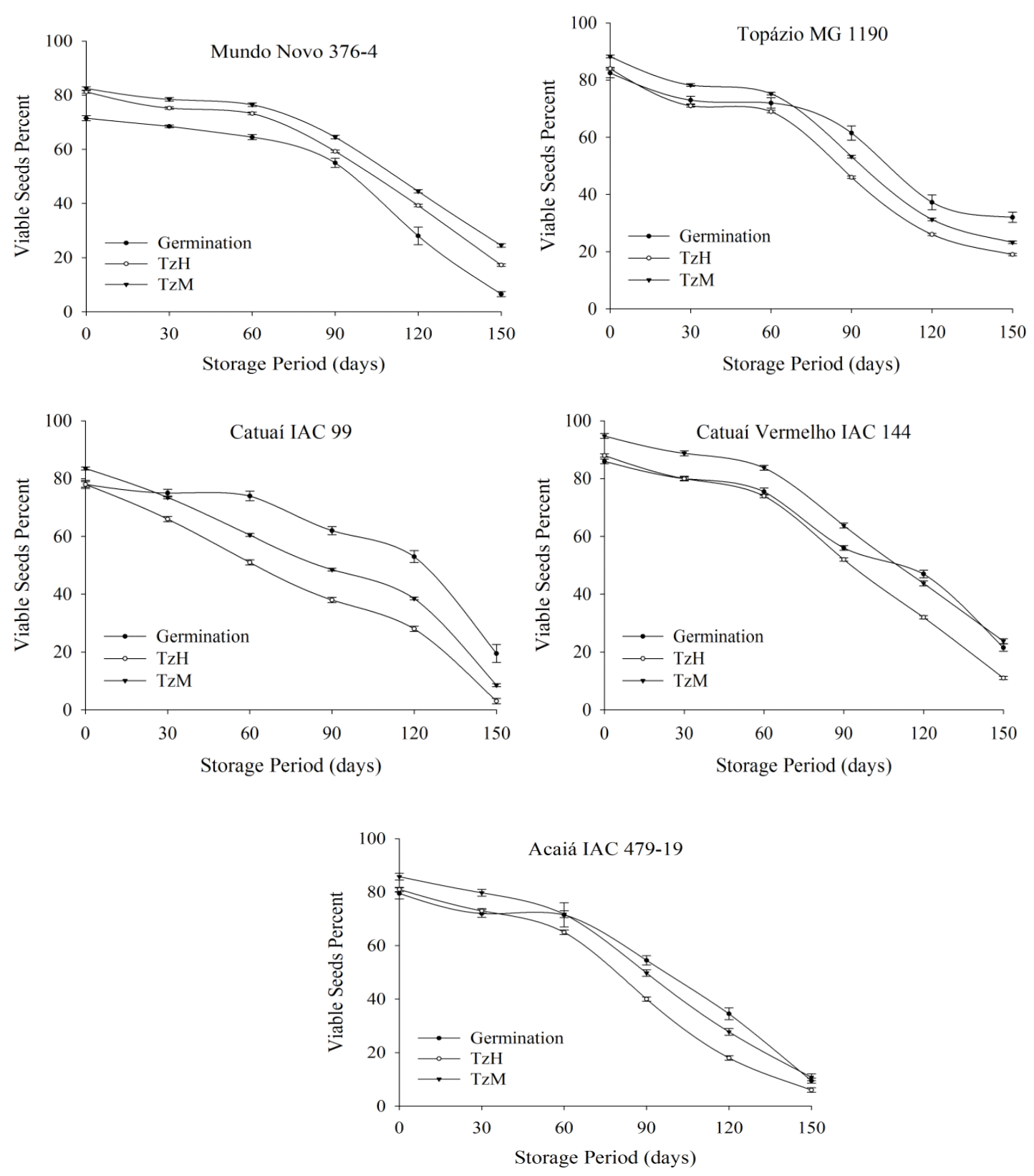

Figure 7 - Germination percentages and viability (Tz) of coffee seeds of 5 cultivars assessed by means of two methodologies for parchment removal (manually - TzM and with sodium hypochlorite - TzH) throughout the storage period.

\section{CONCLUSIONS}

The use of sodium hypochlorite at the concentration of $5 \%$ for 6 hours of imbibition negatively affects the results of the tetrazolium test in coffee seeds with moisture below $25 \%$. Thus, the tetrazolium test on coffee seeds with different moisture and deterioration levels must be performed with manual removal of the parchment.

The 48 hour imbibition period of coffee seeds in the preparation phase facilitates embryo extraction, not affecting the results of the tetrazolium test on coffee seeds. 


\section{REFERENCES}

ARAÚJO, E.F. et al. Efeito da danificação mecânica e da remoção manual do pergaminho sobre a emergência das plântulas de Coffea arabica L. Revista Brasileira de Armazenamento, Viçosa, MG, v.8, p.1-5, jun. 2004. Edição especial.

BEWLEY, J.D.; BLACK, M. Physiology and biochemistry of seeds in relation to germination: viability, dormancy and environmental control. Berlin: Springer-Verlag, 1982. 375p.

BRASIL. Ministério da Agricultura, Pecuária e Abastecimento. Regras para análise de sementes. Brasília, DF: Mapa/ACS, 2009.395p.

DIAS, M.C.L.L.; SILVA, W.R. Determinação da viabilidade de sementes de café através do teste de tetrazólio. Pesquisa Agropecuária Brasileira, Brasília, v.21, n.11, p.1139-1145, nov. 1986.

EIRA, M.T.S. et al. Coffee seed physiology. Brazilian Journal of Plant Physiology, Londrina, v.18, n.1, p.149163, jan./mar. 2006.

FERREIRA, D.F. Sistema de análise estatística - SISVAR. Lavras: DCE, UFLA, 2000. 66 p.

FRANÇANETO, J.B.; KRZYZANOWSKI, F.C.; COSTA, N.P. da. $O$ teste de tetrazólio em sementes de soja. Londrina: EMBRAPA-CNPSo, 1998. 72p. (EMBRAPACNPSo. Documentos, 116).

INSTITUTO MINEIRO DE AGROPECUÁRIA-IMA. Portaria n $\mathbf{n}^{\mathbf{0}}$ 482, de 29 de novembro de 2001. Dispõe sobre normas e padrões para a produção de sementes básicas e fiscalizadas de café. Belo Horizonte, 2001.

KRYZANOWSKI, F.C.; VIEIRA, R.D.; FRANÇANETO, J.B. Vigor de sementes: conceitos e testes. Londrina: ABRATES, 1999. 218p.

MEIRELES, R.C. et al. Secafé: metodologia para acelerar a germinação das sementes de café. Revista Brasileira de Sementes, Londrina, v.29, n.3, p.90-96, jul./set. 2007.

MOORE, R. P. Interpretation of color differences in tetrazolium testing. Seed Technologist News, Zürich, v.44, n.3, p.22-24, jul./set. 1972.
PEREIRA, C.E. at al. Determinação de inibidores da germinação no espermoderma de sementes de café (Coffea arabica L.). Revista Brasileira de Sementes, Londrina, v.24, n.1, p.306-311, jan./mar. 2002.

R DEVELOPMENT CORE TEAM. R, a language and environment for statistical computing. Vienna: $\mathrm{R}$ Foundation for Statistical Computing, 2008. Disponível em: <http://www.R-project.org>. Acesso em: 10 fev. 2009.

ROSA, S. D. V. F. et al. The effect of storage conditions on coffee seed and seedling quality. Seed Science and Technology, Zurich, v.39, n.1, p.151-164, apr. 2011.

Staging coffee seedling growth: a rationale for shortening the coffee seed germination. Seed Science and Technology, Zurich, v. 38, n.2, p.421-431, jul. 2010.

RUBIM, R. F. et al. Tratamento com hipoclorito de sódio para remoção do pergaminho e aceleração da germinação de sementes de café conilon. Revista Brasileira de Sementes, Lavras, v. 32, n.4, p.088 098, out.2010.

SALES, J. F. et al. Efeito da celulase sobre a decomposição do pergaminho e sua influência na velocidade e porcentagem de germinação de sementes de cafeeiro. Ciência e Agrotecnologia. Lavras, v. 29, n.6, p.1146-1152, nov./dez. 2006.

SERA, G.H., MIGLIORANZA, E. Avaliação visual do potencial germinativo de sementes de café pelo formato e coloração do embrião. Semina, Ciências Agrárias, Londrina, v. 24, n. 2, p. 307-310, jul./dez. 2003.

SOFIATTI, V. et al. Uso de hipoclorito de sódio para acelerar a emergência das plântulas e o desenvolvimento das mudas de cafeeiro. Bragantia, Campinas, v.68, n.1, p.233-240, jan./abr. 2009.

SOTO, F.; ECHEVARRIA, I.; RODRIGUEZ, P. Estúdio sobre la conservacion de semillas de cafetos (Coffea Arabica L. variedad Caturra). Cultivos Tropicales, Havana, v.16, n.1, p.33-36, 1995. 
VASCONCELOS, L.M.; GROTH, D.; RAZERA, L.F. Efeito de processos de secagem, diferentes graus de umidade e tipos de embalagens na conservação de sementes de café (Coffea arabica L. cv. Catuaí Vermelho). Revista Brasileira de Sementes, Brasília, v.14, n.2, p.181-188, mar./abr. 1992.

VIEIRA, A.R. et al. Armazenamento de sementes de cafeeiro: ambientes e métodos de secagem. Revista Brasileira de Sementes, Brasília, v.29, n.1, p.76-82, jan./fev. 2007.
VIEIRA, M.G.G.C. et al. Testes rápidos para determinação da viabilidade e da incidência de danos mecânicos em sementes de cafeeiro. Lavras: UFLA, 1998. 34p. (Boletim Agropecuário, 26).

ZONTA, J.B. et al. LERCAFÉ test for the assessment of coffee seed quality during storage. Seed Science and Technology, Zurich, v.37, n.1, p.140-146, apr. 2009. 